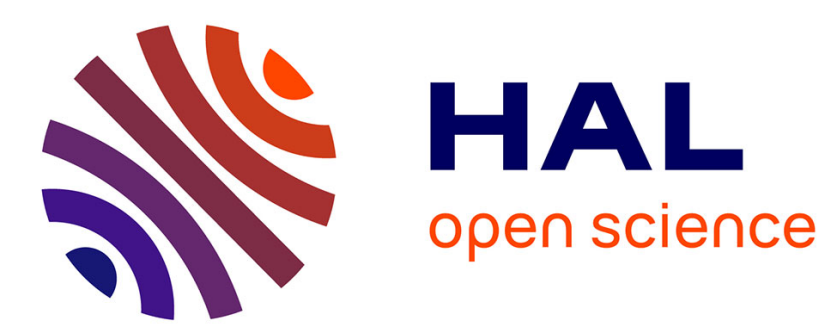

\title{
Genotypic and phenotypic characterization of foodborne Geobacillus stearothermophilus
}

Loïc Durand, Stella Planchon, Marie-Hélène Guinebretière, Frederic Carlin, Fabienne Remize

\section{- To cite this version:}

Loïc Durand, Stella Planchon, Marie-Hélène Guinebretière, Frederic Carlin, Fabienne Remize. Genotypic and phenotypic characterization of foodborne Geobacillus stearothermophilus. Food Microbiology, 2015, 45, pp.103-110. 10.1016/j.fm.2014.01.015 . hal-01447933

\section{HAL Id: hal-01447933 \\ https://hal.univ-reunion.fr/hal-01447933}

Submitted on 25 Sep 2017

HAL is a multi-disciplinary open access archive for the deposit and dissemination of scientific research documents, whether they are published or not. The documents may come from teaching and research institutions in France or abroad, or from public or private research centers.
L'archive ouverte pluridisciplinaire HAL, est destinée au dépôt et à la diffusion de documents scientifiques de niveau recherche, publiés ou non, émanant des établissements d'enseignement et de recherche français ou étrangers, des laboratoires publics ou privés. 


\title{
Genotypic and phenotypic characterization of foodborne Geobacillus stearothermophilus
}

\author{
Loïc Durand ${ }^{a}$, Stella Planchon ${ }^{a}$, Marie-Hélène Guinebretiere ${ }^{b, c}$, Frédéric Carlin ${ }^{b, c}$, \\ Fabienne Remize ${ }^{a_{*} * 1}$ \\ ${ }^{a}$ CTCPA, Site Agroparc, 2A de l'aéroport - BP21203, 84911 Avignon Cedex 9, France \\ ' INRA, UMR 408, Sécurité et Qualité des Produits d'Origine Végétale, F-84000 Avignon, France \\ 'Université d'Avignon et des Pays de Vaucluse, UMR 408, Sécurité et Qualité des Produits d'Origine Végétale, F-84000 Avignon, France
}

\section{A B S T R A C T}

Geobacillus stearothermophilus is the main thermophilic spore former involved in flat sour spoilage of canned foods. Three typing methods were tested and applied to differentiate strains at intraspecies level: panC sequence analysis, REP-PCR and M13-PCR. panC gene was highly conserved within the studied strains, suggesting a low intra-specific diversity. This was supported by REP-PCR primary assays and M13-PCR results. M 13-PCR profile analysis succeeded in differentiating six closely related groups (at 79\% threshold similarity) among 127 strains from a range of spoiled canned food products and from different canneries. Phenotypic traits were investigated among 20 selected strains representing groups and origins. Ranges of growth under different temperatures (from $40{ }^{\circ} \mathrm{C}$ to $70{ }^{\circ} \mathrm{C}$ ), $\mathrm{pH}$ (from 5.0 to 6.5 ), $\mathrm{NaCl}$ concentrations (from 1 to 5\%) and sporulation conditions poorly differed between strains, but wet heat resistance of spores showed a 20-fold variation between strains. Furthermore, in this study, strains that belonged to the same M13-PCR genetic group did not share phenotypic characteristics or common origin. The work emphasizes a low diversity within the G. stearothermophilus species but data from this study may contribute to a better control of $G$. stearothermophilus spoilage in canned food.

\section{Introduction}

Geobacillus stearothermophilus is a thermophilic spore-forming bacterium with optimal growth between $55^{\circ} \mathrm{C}$ and $65^{\circ} \mathrm{C}$ (Nazina et al., 2001). G. stearothermophilus properties interest several industrial sectors, as a source of enzymes with high temperature stability, producer of antiviral compounds, biological indicator for sterility control, and as a major cause of food spoilage (Cheng et al., 2009; Guizelini et al., 2012; Rivero et al., 2012). G. stearothermophilus is responsible for "flat-sour" spoilage of lowacid canned food stored at high temperature (above $40^{\circ} \mathrm{C}$ ) (Ashton and Bernard, 1992). "Flat sour" results from saccharide fermentation into organic acids without gas production (KalogridouVassiliadou, 1992). G. stearothermophilus spores can withstand

\footnotetext{
* Corresponding author. UMR QualiSud, Universitéde Ia Réunion - ESIROI, 2 rue Joseph Wetzell, Parc Technologique Universitaire, F-97490 Sainte Clotilde, France. Tel.: +262 692200785 .

E-mail address: fabienne.remize@univ-reunion.fr (F. Remize).

1 Present address: UMR QıaliSud, Université de la Réunion, Sainte-Clotilde, France.
}

canned food heat treatment and can further germinate and grow in products. G. stearothermophilus is responsible for $c a$. $35 \%$ of canned food spoilage during incubation at $55^{\circ} \mathrm{C}$ (Ashton and Bernard, 1992; André et al., 2013). It has been detected in many raw and processed foods (canned vegetables, ready-to-eat meals containing meat, fruit preparations, dehydrated ingredients, gelatin extracts...) (Postollec et al., 2012) and in processing facilities. For instance up to $50 \%$ milk powders may contain the bacterium, which may represent more than $10 \%$ of thermophilic isolates (Rückert et al., 2004) and G. stearothermophilus spores were detected in $8.6 \%$ and $2.1 \%$ of raw carrots and green bean samples, respectively (Sevenier et al., 2012).

High prevalence in food has supported the characterization of G. stearothermophilus isolates for survival and growth in canned food, without clear evidence of the variability within the species (Donk, 1920; Gordon and Smith, 1949; Smith and Gordon, 1957; Gibson and Gordon, 1974; Kalogridou-Vassiliadou, 1992; White et al., 1993; Nazina et al., 2001; Coorevits et al., 2012). Genomic studies are now increasingly carried out on thermophilic bacteria to determine the extent of variability and diversity within bacterial groups or species. Several strategies and methods can be used. For 
instance these include rep-PCR profiling and 16S rRNA coding region sequencing applied on thermophilic bacteria from hot springs (Adiguzel et al., 2009), RAPD-PCR or MLVA applied to differentiate thermophilic bacilli in milk powder and tracking of contamination in dairy processing plants (Ronimus et al., 2003; Rückert et al., 2004). Sequencing methods that target highly conserved housekeeping genes such as $r e c N, r p o B$ and $r e c A$ have been applied to the Geobacillus genus (Zeigler, 2005; Meintanis et al., 2008; Weng et al., 2009; Seale et al., 2012). The diversity of the pathogenic and sporeforming bacterium Bacillus cereus was also investigated with success using a M13 sequence-based polymerase chain reaction (M13PCR) (Guinebretiere and Nguyen-The, 2003), panC sequencing and AFLP (Guinebretiere et al., 2008). Analysis of 16S rRNA gene sequence was not discriminatory enough for $G$. stearothermophilus (Dinsdale et al., 2011). In this case, panC gene phylogeny could be used as an alternative to $16 \mathrm{~S}$ rRNA gene phylogeny, as with $B$. cereus (Guinebretiere et al., 2008). Sequence (or partial sequence) of the coliphage M13 is repeated on many genomes and was exploited as primer in DNA sequence based PCR (M13-PCR) (Henderson et al., 1994; Guinebretiere and Nguyen-The, 2003). This resulted in a more rapid DNA fingerprinting technique that discriminates bacterial isolates at the intra-specific level, and potentially up to the strain level. As for RAPD and REP-PCR, M13-PCR is less cumbersome and time-consuming than other typing methods such as genotyping, ribotyping, RFLP, PCR-RFLP and AFLP, and is adapted to studies on a large number of strains (i.e. $>100$ ). In addition, M13-PCR involves a longer primer and higher hybridization temperatures than RAPD and thus results in more reproducible results.

The aims of this work were (i) to compare the ability of three typing methods (M13-PCR, REP-PCR and panC sequencing) to differentiate $G$. stearothermophilus genetic groups, (ii) to evaluate the genetic diversity among a large panel of $G$. stearothermophilus strains from spoiled canned food, and (iii) to explore their phenotype in relation to ability to grow at different temperatures, $\mathrm{pH}$ and salt concentrations, ability to sporulate, and spore resistance to heat treatment.

\section{Materials and methods}

\subsection{Strains and culture conditions}

A total of 127 G. stearothermophilus strains were tested (Supplementary Table 1). Among those, 116 strains were recovered between 2001 and 2010 from spoiled canned food after long-term storage at $55{ }^{\circ} \mathrm{C}$ (André et al., 2013). Two isolates (\#110 and \#112) were isolated from vegetable debris sampled in a cannery blancher. Three isolates (\#82, \#85 and \#86) were isolated from the covering brine of canned vegetable, and one isolate, \#63, was isolated from a cannery conveyor surface. They were identified as G. stearothermophilus using either a specifically developed PCR tool (SporeTraQ ${ }^{\mathrm{TM}}$ ) (Prevost et al., 2010) that targets the DNA region corresponding to rRNA internal transcribed sequence $16 \mathrm{~S}-23 \mathrm{~S}$, or a partial sequencing of $16 \mathrm{~S}$ rRNA coding region. Five other G. stearothermophilus strains were obtained from the DSMZ collection (Deutsche Sammlung von Mikroorganismen und Zellkulturen, Braunschweig, Germany). DSM 22 and DSM 297 were isolated from spoiled canned food. The origin of DSM 5934, DSM 2313 and DSM 6790 strains is not specified. Strains were stored at $-80^{\circ} \mathrm{C}$ in a cryogenic preservative solution with beads (AES Chemunex, Bruz, France).

A bead of a stock culture was dropped into brain heart infusion (BHI) before incubation for $48 \mathrm{~h}$ at $55^{\circ} \mathrm{C}$. A $500 \mu \mathrm{l}$ volume of this pre-culture was inoculated into $\mathrm{BHI}$ and incubated overnight at $55^{\circ} \mathrm{C}$. The resulting culture was used for subsequent inoculation of growth and sporulation media.

\subsection{Genetic groups and diversity}

\subsubsection{DNA extraction}

A $100 \mu \mathrm{l}$ volume of an overnight culture in BHI was spread on dextrose tryptone agar (DTA) and incubated for $16 \mathrm{~h}$ at $55^{\circ} \mathrm{C}$ before DNA extraction. DNA preparation was obtained as described previously (Guinebretiere and Nguyen-The, 2003) with minor modifications. Two loops of cells were suspended in $550 \mu$ l extraction buffer (1.7\% sodium dodecyl sulfate, $200 \mathrm{mM}$ Tris- $\mathrm{HCl}(\mathrm{pH} 8)$, $20 \mathrm{mM}$ EDTA, $200 \mathrm{mM} \mathrm{NaCl})$. The suspension was incubated at $55^{\circ} \mathrm{C}$ for 30 min with $25 \mu$ l of proteinase $\mathrm{K}\left(10 \mu \mathrm{g} \mu \mathrm{l}^{-1}\right.$ ) (SigmaAldrich, Saint-Quentin-Fallavier, France). DNA was extracted with one volume of phenol. After centrifuging, the aqueous phase containing DNA was mixed with one volume of phenol, recovered after centrifuging, and then mixed with one volume of chloroform. The aqueous phase was precipitated with cold absolute ethanol. After centrifuging, the pellet was washed with cold $70 \%$ ethanol, air dried at room temperature, dissolved in $50 \mu \mathrm{l}$ sterile Milli-Q water, and stored at $-20^{\circ} \mathrm{C}$. DNA was quantified by absorbance at $260 \mathrm{~nm}$ (NanoQuant Plate ${ }^{\mathrm{TM}}$ Infinite ${ }^{\circledR} \mathrm{M} 200$, Tecan Austria). The DNA was extracted from three independent cultures of randomly selected 24 strains to evaluate the reproducibility of genomic analyses.

\subsection{2. $M 13-P C R$}

The method used followed the PCR protocol as previously described with minor modifications (Guinebretiere and NguyenThe, 2003). PCR mix (25 $\mu \mathrm{l})$ contained $50 \mathrm{ng}$ of DNA template, 4.8 mM primer PM13: 5'-GAGGGTGGCGGCTCT-3' (Eurogentec S.A., Seraing, Belgium), $1.25 \mathrm{mM}$ dNTPs mix (Eurogentec), $6 \mathrm{mM} \mathrm{MgCl} 2$ (Sigma-Aldrich), 10\% (vol/vol) dimethyl sulfoxide (Sigma-Aldrich), and $1.5 \mathrm{U}$ of Diamond $\mathrm{Taq}^{\circledR}$ DNA polymerase (Eurogentec) in supplier buffer. PCR amplifications were performed in a GeneAmp ${ }^{8}$ PCR System 9700 (Applied Biosystems, USA). PCR cycling parameters included a denaturation step at $94^{\circ} \mathrm{C}$ for 3 min followed by 35 cycles each consisting of $94^{\circ} \mathrm{C}$ for $1 \mathrm{~min}, 40^{\circ} \mathrm{C}$ for $1 \mathrm{~min}$ and $68^{\circ} \mathrm{C}$ for $8 \mathrm{~min}$; and a final extension step at $68^{\circ} \mathrm{C}$ for $16 \mathrm{~min}$. A negative control containing Milli-Q water instead of DNA and a positive control with the DNA of $B$. cereus strain ATCC 14579 producing a known banding pattern were included in each PCR experiment. All of the DNA preparations were analyzed by M13-PCR twice independently to evaluate the reproducibility of the typing results.

\subsubsection{REP-PCR analysis}

A set of 24 strains underwent REP-PCR genomic fingerprinting as previously described (Versalovic et al., 1994). Amplification was performed as described above, except that $2.4 \mu \mathrm{M}$ of each primer REP 1R-I ( $5^{\prime}$ III IGC ICG ICG ICA TCI GGC $\left.3^{\prime}\right)$ and REP 2-I ( $5^{\prime}$ ICG ICT TAT CIG GCC TAC $3^{\prime}$ ) (Eurogentec) was used, and PCR elongation was performed at $65^{\circ} \mathrm{C}$.

\subsection{4. panC sequencing}

The oligonucleotides used for the PCR amplification of panC encoding pantoate- $\beta$-alanine ligase were: PCF3, 5'-TCGGDTTYGTNCCGACGATGG- $3^{\prime}$ and PCR1, 5'-AAABCGVACGGCVACVGCGA-3'. They were designed from sequence alignment of panC genes from several Geobacillus sp. (accession numbers: CP001794, CP002442, CP002050, CP001638, CP002293, NC_006510, and CP003125). Amplification reaction was performed in a final volume of $25 \mu \mathrm{l}$ containing DNA template (50 ng), dNTPs mix (Eurogentec) ( $0.2 \mathrm{mM}), \mathrm{MgCl}_{2}(2 \mathrm{mM})$, primers $(0.4 \mu \mathrm{M}$ each), and $0.5 \mathrm{U}$ of Diamond Taq ${ }^{\circledast}$ DNA polymerase (Eurogentec) in supplier buffer. The cycling program was $94^{\circ} \mathrm{C}$ for $4 \mathrm{~min}$; 35 cycles of $94^{\circ} \mathrm{C}$ for $40 \mathrm{~s}$, $64^{\circ} \mathrm{C}$ for $40 \mathrm{~s}$ and $72{ }^{\circ} \mathrm{C}$ for $1 \mathrm{~min}$; and a final extension at $72{ }^{\circ} \mathrm{C}$ for $10 \mathrm{~min}$. PCR product was purified with the High Pure PCR Product Purification Kit according to the manufacturer's instructions 
(Roche, France). The partial sequencing of the panc gene (648 pb) was done with the PCF3 primer by Eurofins MWG Operon (Courtaboeuf, France) according to the classical Sanger method. The 20 panC sequences were registered in GenBank under accession numbers KF177233 to KF177252. Sequence alignment was carried out with Clustal Omega at EBI-EMBL (Goujon et al., 2010; Sievers et al., 2011). Percentages of identity were calculated between these sequences and other thermophilic spore-forming bacteria panC sequences (accession numbers: NC_006274, NC_004722, NC_003909, NC_006510 and CP000232) available in the GenBank database.

\subsubsection{Electrophoresis and data analysis}

PCR products from M13-PCR and REP-PCR were analyzed by electrophoresis on $1.5 \%$ agarose gels with the molecular mass DNA marker Smart Ladder (Eurogentec) using $0.5 \times$ TAE buffer $(20 \mathrm{mM}$ Tris, $10 \mathrm{mM}$ acetic acid, $0.5 \mathrm{mM}$ EDTA, pH 8). Gels were stained with ethidium bromide and visualized and photographed on a UV gel imager (Molecular Imager ${ }^{\circledast}$ Gel Doc ${ }^{\mathrm{TM}}$ XR System 170-8170, BioRad, France). Band position, similarity coefficient and dendrogram were determined using the BioGene 99.04 software (Vilber Lourmat, Marne-la-Vallée, France). A dendrogram was constructed from the similarity banding pattern of M13-PCR amplification using the unweighted pair group method with arithmetic mean (UPGMA). $B$. cereus ATCC 14579 was chosen as positive control to evaluate the variability generated by the analyses (PCR-electrophoresis-image analysis). Amplification product from the positive control was deposited on each gel, and results were compared to define the confidence interval.

\subsection{Growth studies}

\subsubsection{Growth at different temperatures and $\mathrm{pH}$}

Growth at a range of temperature and $\mathrm{pH}$ was tested on dextrose tryptone agar (DTA) and in DT broth (DTB) selected for its color stability at high temperature that favors reading. Inoculums were made of an overnight culture in BHI broth diluted 100-fold in peptone salt water to obtain suspensions at $10^{5} \mathrm{CFU} \mathrm{ml}^{-1}$. In a first step one a droplet ( $10 \mu \mathrm{l})$ of each bacterial suspension was deposited on DTA. Plates were wrapped in aluminum foil to avoid desiccation and incubated for 14 days. Growth was tested at each of the 24 combinations of incubation temperature $\left(45^{\circ} \mathrm{C}, 50^{\circ} \mathrm{C}, 55^{\circ} \mathrm{C}\right.$ or $\left.70^{\circ} \mathrm{C}\right)$ and $\mathrm{pH}(6.5,6.0,5.5,5.0,4.8$ and 4.5$)$. Growth at $40^{\circ} \mathrm{C}$ was tested only on DTA $\mathrm{pH} 6.5$. The $\mathrm{pH}$ adjustment was performed in sterilized molten DTA by addition of filter-sterile $2 \mathrm{~N} \mathrm{HCl}$ (Fischer Scientific SAS, Illkirch, France). Strains were deemed positive for growth when the diameter of the colony formed from the droplet inoculum at the agar surface was greater than $1 \mathrm{~mm}$. Colony development was examined daily after $48 \mathrm{~h}$ of incubation, until 14 days.

In a second step strains that were negative in at least one combination of $\mathrm{pH}$ and temperature were tested in (DTB) to differentiate between absence of growth and weak growth. A $500 \mu \mathrm{l}$ volume of an overnight culture was inoculated in DTB sterilized at $121.1^{\circ} \mathrm{C}$ for $15 \mathrm{~min}$ and incubated at $45^{\circ} \mathrm{C}, 50^{\circ} \mathrm{C}, 55^{\circ} \mathrm{C}$ and $70^{\circ} \mathrm{C}$, adjusted to the required $\mathrm{pH}$ with filter-sterile $2 \mathrm{~N} \mathrm{HCl}$ for a maximum of 14 days. Growth was controlled every $24 \mathrm{~h}$ by serial decimal dilution of the culture onto DTA and colony enumeration after $48 \mathrm{~h}$ incubation at $55^{\circ} \mathrm{C}$. Strains were deemed positive when they showed at least one $1 \log$ cfu.ml ${ }^{-1}$ increase in DTB after 14 days of incubation. Growth at $37^{\circ} \mathrm{C}, 39^{\circ} \mathrm{C}, 40^{\circ} \mathrm{C}, 72^{\circ} \mathrm{C}$ and $75^{\circ} \mathrm{C}$ at $\mathrm{pH} 6.5$ was tested in DTB during incubation for 14 days using the same enumeration procedure and was replicated three times with independently prepared inoculums. Incubation temperatures at $37^{\circ} \mathrm{C}, 39^{\circ} \mathrm{C}, 40{ }^{\circ} \mathrm{C}, 72^{\circ} \mathrm{C}$ and $75^{\circ} \mathrm{C}$ were obtained in a thermo- stated water-bath and temperature was monitored using a digital thermometer (EcoScan Temp5, Fisher, Illkirch, France).

\subsubsection{Growth at different sodium chloride concentrations}

DTA was supplemented with sodium chloride to obtain final concentrations in the range $1-5 \%(w t / v o l)$. The previously described drop method was used to inoculate the medium. Water activity $\left(a_{\mathrm{w}}\right)$ DTA was measured for each $\mathrm{NaCl}$ concentration (AquaLab, Biotrace International SAS). Incubation was performed at $55{ }^{\circ} \mathrm{C}$ for a maximum of 14 days. Strains were deemed positive for growth, as colony diameter at the agar surface was greater than $1 \mathrm{~mm}$.

\subsection{Spore production and evaluation of spore heat resistance}

\subsubsection{Spore production and percentage of sporulation}

For spore production, a $2 \mathrm{ml}$ volume of an overnight culture in BHI was spread onto the sporulation medium (SM) on a $145 \mathrm{~mm}$ agar plate. The sporulation medium was made of $10 \mathrm{~g} \mathrm{l}^{-1}$ meat extract, $2 \mathrm{~g} \mathrm{l}^{-1}$ yeast extract, $0.04 \mathrm{~g} \mathrm{l}^{-1} \mathrm{MnSO}_{4} \cdot \mathrm{H}_{2} \mathrm{O}$ and $15 \mathrm{~g} \mathrm{l}^{-1}$ agar. Temperatures tested for sporulation were $40,45,55$ and $70^{\circ} \mathrm{C}$. The spores were also examined under a phase-contrast microscope under a $\times 1000$ magnification to estimate the $\%$ of sporulation as the $\%$ of phase bright and free spores within the sporulating population after 21 days of incubation at selected temperature and $\mathrm{pH}$. Approximately $30-50$ cells were counted in 10 observation fields for each different strain. Spores were harvested when the culture contained more than $50 \%$ of free spores. Harvested spores were washed with $5 \mathrm{ml}$ of sterile distilled water, pelleted at $1400 \times \mathrm{g}$ for $20 \mathrm{~min}$ at $4{ }^{\circ} \mathrm{C}$, and suspended again in $5 \mathrm{ml}$ of sterile distilled water. This procedure was replicated four times. Residual vegetative cells and germinated spores were killed by heating suspensions at $100{ }^{\circ} \mathrm{C}$ for $10 \mathrm{~min}$. Spore suspensions were stored for 15 days at $4{ }^{\circ} \mathrm{C}$. These spore suspensions were heated at $100{ }^{\circ} \mathrm{C}$ for $10 \mathrm{~min}$ for counting. One batch of spores was prepared for each strain.

\subsubsection{Spore heat resistance and curve fitting with mathematical models}

Heat resistance at $120{ }^{\circ} \mathrm{C}$ was determined as previously described (André et al., 2013). The number of surviving spores in capillary tubes was evaluated after $0.5,1,1.5,2,2.5,3,3.5,4,6$ and $8 \mathrm{~min}$. Serial decimal dilutions of the content of capillary tubes in $0.2 \mathrm{M}$ phosphate buffer were spread onto bromocresol purple (BCP), and then covered with layer of molten $\mathrm{BCP}$ at $50{ }^{\circ} \mathrm{C}$. Plates were incubated at $55^{\circ} \mathrm{C}$ for 2 days before colony counts. The time for a 5 - $\log _{10}$ reduction $\left(t_{5 D}\right)$ was used to compare the heat resistance of isolates, to take into account the different forms of survival curves (linear, concave or convex) and to account for a large number of log-reduction. Graphical log plots of surviving population vs heating time $\left(\log \mathrm{CFU} \mathrm{ml}{ }^{-1}=f(t)\right)$ were fitted according to three equation models: log-linear, biphasic log-linear and Weibull.

The log-linear model is based on the following equation:

$\log N=\log N_{0}-\frac{t}{D}$

where $N_{0}$ and $N$ are the initial and final number of cells (CFU ml${ }^{-1}$ ) after a treatment time $t(\mathrm{~min})$, respectively, and $D$ is the decimal reduction time ( $\mathrm{min})$.

The biphasic log-linear model was applied with the following equation:

$\log N=\left\{\begin{array}{lll}\log N_{0} & \text { if } t \leq \text { lag } \\ \log N_{0}-\frac{t}{D} & \text { if } t>\text { lag }\end{array}\right.$ 
where $N_{0}$ and $N$ are the initial and final number of cells (CFU ml${ }^{-1}$ ) after a treatment time $t(\mathrm{~min})$, respectively, $D$ is the decimal reduction time ( $\mathrm{min})$, and lag the duration of the latency phase.

The Weibull model (Couvert et al., 2005) was applied with the equation:

$\log N=\log N_{0}-\left(\frac{t}{\delta}\right)^{p}$

where $N_{0}$ and $N$ are the initial and final number of cells (CFU ml ${ }^{-1}$ ) after a treatment time $t(\mathrm{~min})$, respectively, $\delta$ is the first reduction decimal time (min) that leads to a 10 -fold reduction in surviving population, and $p$ is the fitting parameter. The equation that generates the lowest residual sum of squares (RSS) was used to calculate the time for a $5-\log _{10}$ reduction $\left(t_{5 D}\right)$.

\subsection{Statistical analysis}

Qualitative data of the tested variables were analyzed by multiple correspondence analysis (MCA) with the software XLSTAT (AddinsoftTM, Paris, France). The variables tested were either (i) food category/product for isolation, food company, geographical location and year of isolation, or (ii) lowest temperature, highest temperature, lowest $\mathrm{pH}$, highest $\mathrm{pH}$ and highest $\mathrm{NaCl}$ concentration at which a growth was observed. Observations were isolate numbers and M13-PCR group numbers.

\section{Results and discussion}

\subsection{Genetic diversity of $G$. stearothermophilus strains examined with M13-PCR, REP-PCR and panC sequencing}

An ideal genotyping method should be applicable to all isolates, capable of differentiating unrelated isolates, reproducible both within and between laboratories, rapid, cost-effective, and easy to perform. In this study, M13-PCR, REP-PCR and panC sequencing were applied within the species $G$. stearothermophilus. All three techniques had previously been used successfully for species typing in the genus Bacillus (Guinebretiere et al., 2001; Guinebretiere and Nguyen-The, 2003; Guinebretiere et al., 2008).

An internal region of panc gene was sequenced for 20 selected strains. A $82.7 \%$ sequence identity was obtained with Geobacillus kaustophilus HTA426 panC gene, validating identity of sequences obtained with that method. When compared with the reference G. stearothermophilus DSM 22, sequence identity of obtained sequences ranged from $99.4 \%$ to $100 \%$. These results indicate that panc gene is probably highly conserved within the G. stearothermophilus species. We thus expect a low diversity in this species. For this reason panC sequence could not be used as a phylogenetic tool for $G$. stearothermophilus strains isolated from canned food spoilage. The low intra-specific diversity in G. stearothermophilus species is also underlined by numerous bibliographic data : the $r p o B$ housekeeping gene exhibited more than $74 \%$ of identity within Geobacillus spp. (Meintanis et al., 2008); $r e c A$ and $r p o B$ gene sequence comparison discriminates only among Geobacillus species (Weng et al., 2009); recN is a powerful tool to differentiate species of Geobacillus but failed to differentiate strains at intraspecific level (Zeigler, 2003). Also, the use of the sequence 16S-23S rRNA internal transcribed spacers (ITS) have shown no phylogenetic relationships between the different species of $\mathrm{Geo}$ bacillus (Xu and Côté, 2003; Kuisienè et al., 2008), which decrease the interest of use it. All these bibliographic data together with panC sequence analysis from this study converge to a low intraspecific diversity in $G$. stearothermophilus.

A series of naturally-occurring repetitive DNA sequences are dispersed in multiple copies throughout bacterial genomes (Gilson et al., 1984; Stern et al., 1984; Hulton et al., 1991; Lupski and Weinstock, 1992; Koeuth et al., 1995). Although the functions of these interspersed repetitive DNA elements remain unknown, their presence is useful for DNA fingerprinting of bacteria. REP-PCR was successfully used by Meintanis et al. (2008) to discriminate Geobacillus and Bacillus species type strains. In this study, the REP-PCR method was performed on 24 isolates that differed by their isolation origin. A maximum of three to five bands only was observed on the banding patterns, and most of strains exhibited similar electrophoretic profiles, which was not sufficient to efficiently discriminate the isolates (data not shown). In contrast to M13-PCR, the REP-PCR technique resulted in a low number of signals on the banding patterns Hence REP-PCR was not kept to characterize more specifically $G$. stearothermophilus isolates.

Another method that uses a DNA sequence repeated within genomes is M13-PCR. An example of fingerprints generated using M13-PCR on DNA extracted from 20 isolates out of the 127 G. stearothermophilus isolates from this study is shown in Fig. 1.The number of detected DNA bands varied up to 20 and band size ranged between 100 and 5000 bp with a confidence interval of $9 \%$. A M13-PCR profile was obtained for each of the 127 strains. A dendrogram was constructed to compare G. stearothermophilus isolates (Fig. 2). A confidence interval of $9 \%$ was obtained from positive controls from three independent DNA preparations, each

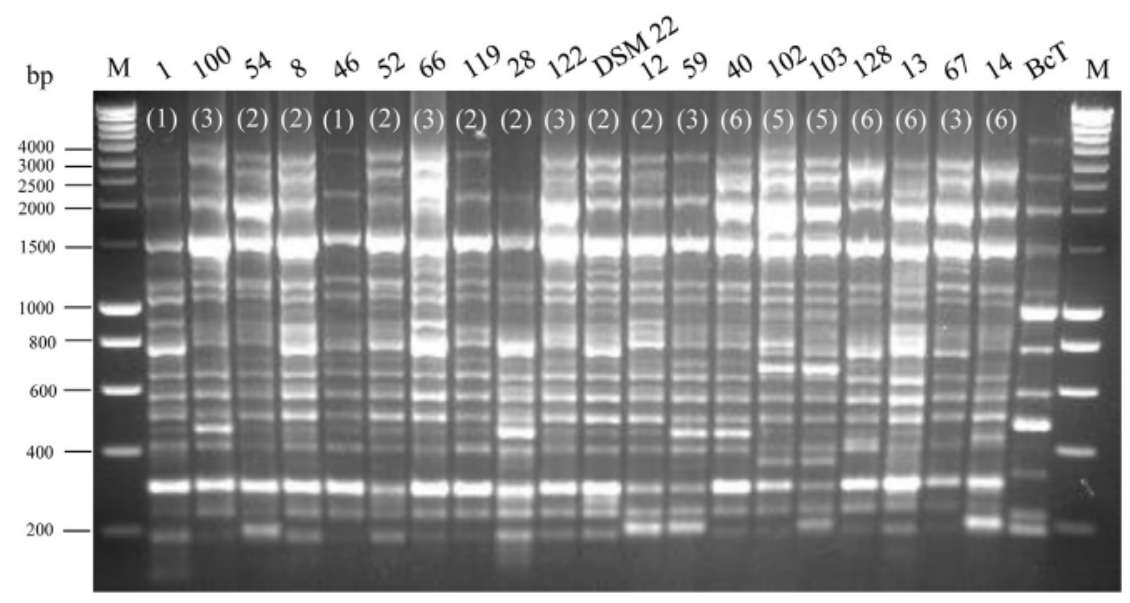

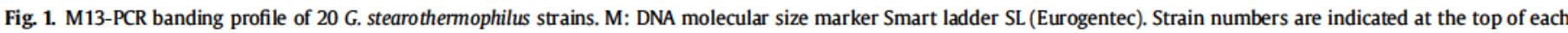
lane, with group numbers between brackets. BCT, B. cereus ATCC 14579 positive control. 


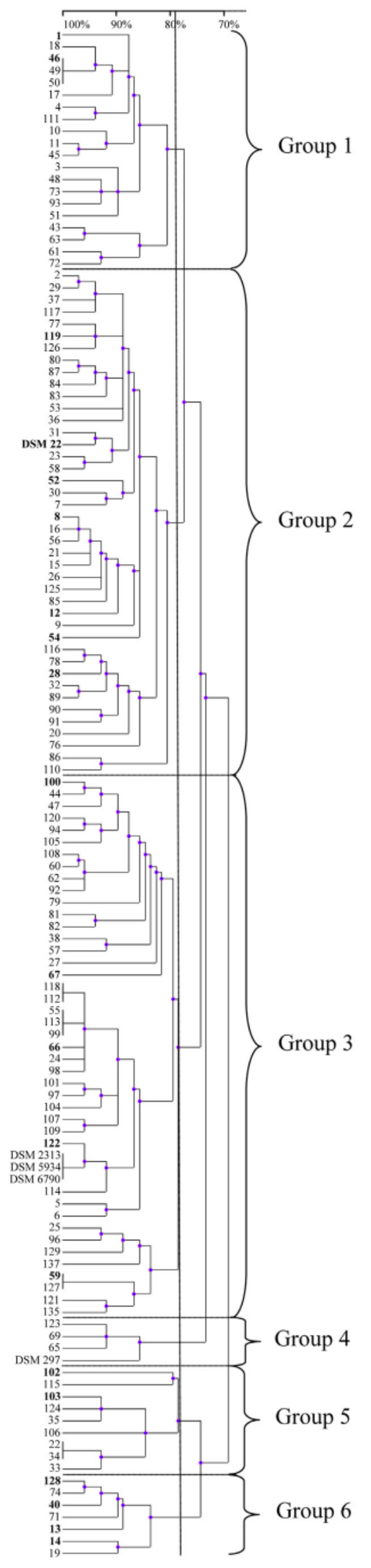

assayed in triplicate by independent PCR, electrophoresis and electrophoretic profiles analysis. Six closely related groups among the 127 isolates of G. stearothermophilus were obtained at a similarity threshold of 79\%, using Dice's coefficient and UPGMA clustering methods (Fig. 2 and Supplementary Table 1). The groups differed by the number of isolates: $84 \%$ of strains belonged to the first three groups, named 1 (16\%), 2 (33\%) and 3 (35\%). The other three groups, named 4, 5 and 6, contained four (3\%), nine (7\%) and seven (6\%) strains respectively. Three DSM collection strains DSM 2313, DSM 5934 and DSM 6790 were found in Group 3. DSM 22 and DSM 297 were respectively in groups 2 and 4. Despite the great differences between origins of strains (geographic area, food product, Food Company and year of isolation, see Supplementary Table 1), the similarity between M13-PCR profiles was high (Figs. 1 and 2), reaching more than $75 \%$ similarity for 107 strains ( $84 \%$ of strains) and more than $69 \%$ for all strains. This emphasized the low intra-specific diversity suggested in G. stearothermophilus by the high panC sequence identity percent. However, M13-PCR had success in differentiating closely related strains. In particular, some strains exhibited one or two specific bands in their profile that could allow recognizing them. Thus, this may be an important tool to trace G. stearothermophilus spoilers on the food processing chain.

3.2. Growth of selected G. stearothermophilus strains at a range of temperature, $\mathrm{pH}$ and $\mathrm{NaCl}$ concentrations and rates of sporulation

Several strains were chosen on the basis of their different origin and their different genetic profile (groups 1, 2, 3, 5 and 6 in the present work) to estimate the phenotypic diversity among G. stearothermophilus strains isolated from canned food. A set of 19 strains that differed by their isolation origin and the type strain DSM 22 were tested for their ability to grow at pH between 4.5 and 6.5 and between $37{ }^{\circ} \mathrm{C}$ and $75^{\circ} \mathrm{C}$ (Table 1). All strains exhibited growth in less than $48 \mathrm{~h}$ at $50^{\circ} \mathrm{C}$ at the three initial $\mathrm{pH}$ values of 6.5 , 6.0 and 5.5 , as well as at $55^{\circ} \mathrm{C}$ and $70^{\circ} \mathrm{C}$, but only for initial $\mathrm{pH}$ values of 6.5 and 6.0. At an initial $\mathrm{pH}$ value of 5.0, only six strains grew at $50^{\circ} \mathrm{C}$, only three at $55^{\circ} \mathrm{C}$, and none at $70^{\circ} \mathrm{C}$. No strain was able to grow at $\mathrm{pH} 4.8$ and below at $50^{\circ} \mathrm{C}$ within 14 days. The most low-pH-tolerant strains were isolate \#122 and the type strain DSM 22 . At the most favorable initial $\mathrm{pH}$ of 6.5 , growth was undetected for all strains at $72^{\circ} \mathrm{C}$, and $75^{\circ} \mathrm{C}$. At this $\mathrm{pH}$, the lowest temperature that allowed growth for 12 isolates was $40^{\circ} \mathrm{C}$. Strains \#28 and \#67 grew in $48 \mathrm{~h}$ at $40^{\circ} \mathrm{C}$. None of the 20 tested strains was able to grow at $39^{\circ} \mathrm{C}$ and $37^{\circ} \mathrm{C}$. At pH 5.5 , growth ability at $70^{\circ} \mathrm{C}$ differed according to the strain: only strains \#28, \#46, \#102, \#103 and \#128 grew, and that growth was observed within $48 \mathrm{~h}$. Interestingly, isolate \#28 exhibited a rapid growth at $40^{\circ} \mathrm{C} \mathrm{pH} 6.5$, at $70^{\circ} \mathrm{C} \mathrm{pH} 6.5$ and at $50{ }^{\circ} \mathrm{C} \mathrm{pH} 5$. Conversely, temperature and $\mathrm{pH}$ ranges of growth were restricted for isolate \#119.

Growth in the presence of $\mathrm{NaCl}$ was assayed for the same strains in a concentration range of $1-5 \%$ (Table 2 ). The results showed that all strains grew at $1 \%$ and $2 \%$, but only 12 and three strains (\#40, $\# 100$ and \#102) were able to develop at $3 \%$ and $4 \% \mathrm{NaCl}$ respectively (Table 3).

All strains grew at $50^{\circ} \mathrm{C}$ and $55^{\circ} \mathrm{C}$ and $\mathrm{pH} 6.0$ and 6.5 , including in the presence of $2 \% \mathrm{NaCl}$. Many of our observations are in accordance with characters reported in the taxonomic revision of the genus Geobacillus (Coorevits et al., 2012; Ronimus et al., 2003):

Fig. 2. Dendrogram of G. stearothermophilus genotypes obtained with the M13-PCR method. The percentage similarities were calculated using Dice's coefficient and UPGMA clustering methods. The groups were formed with a similarity level at 79\% similarity (represented by a vertical scale). Strains with M13-PCR profiles in Fig. 1 are indicated with bold characters. 
Table 1

Growth of G. stearothermophilus strains at different initial $\mathrm{pH}$ and temperatures.

\begin{tabular}{|c|c|c|c|c|c|c|c|c|c|c|c|}
\hline \multirow{3}{*}{$\begin{array}{l}\text { Strain number } \\
\text { (M13 group) }\end{array}$} & \multicolumn{11}{|c|}{ Time to growth at indicated $\mathrm{pH}$ and temperature $\left({ }^{\circ} \mathrm{C}\right)^{\mathrm{a}}$} \\
\hline & \multicolumn{3}{|c|}{$\mathrm{pH} 6.5$} & \multicolumn{2}{|c|}{$\mathrm{pH} 6.0$} & \multicolumn{4}{|c|}{ pH 5.5} & \multicolumn{2}{|c|}{ pH 5.0} \\
\hline & $\begin{array}{l}50 \\
55 \\
70^{b}\end{array}$ & 45 & 40 & $\begin{array}{l}50 \\
55 \\
70^{b}\end{array}$ & 45 & 70 & 55 & 50 & 45 & 55 & 50 \\
\hline \#1 (1) & 2 & 4 & $>4$ & 2 & 4 & ng & 3 & 2 & $\mathrm{ng}$ & ng & $\mathrm{ng}$ \\
\hline \#46 (1) & 2 & 4 & ng & 2 & 4 & 2 & 3 & 2 & ng & ng & ng \\
\hline \#8 (2) & 2 & 4 & ng & 2 & 4 & $\mathrm{ng}$ & 4 & 2 & ng & ng & $\mathrm{ng}$ \\
\hline \#12 (2) & 2 & 4 & $>4$ & 2 & 4 & $\mathrm{ng}$ & 3 & 2 & ng & ng & ng \\
\hline \#28 (2) & 2 & 2 & 2 & 2 & 4 & 2 & 3 & 2 & ng & 4 & 4 \\
\hline \#52 (2) & 2 & 4 & 4 & 2 & 4 & ng & 3 & 2 & 4 & $\mathrm{ng}$ & 3 \\
\hline \#54 (2) & 2 & 4 & 4 & 2 & 4 & ng & 3 & 2 & 4 & ng & $\mathrm{ng}$ \\
\hline \#119(2) & 2 & ng & $\mathrm{ng}$ & 2 & $\mathrm{ng}$ & ng & 3 & 2 & ng & ng & ng \\
\hline DSM $22(2)$ & 2 & 4 & 4 & 2 & 4 & ng & 3 & 2 & ng & 4 & 2 \\
\hline \#59 (3) & 2 & 4 & $\mathrm{ng}$ & 2 & 4 & ng & 4 & 2 & $\mathrm{ng}$ & $\mathrm{ng}$ & ng \\
\hline \#66 (3) & 2 & 4 & 4 & 2 & 4 & ng & 3 & 2 & 4 & ng & ng \\
\hline \#67 (3) & 2 & 2 & 2 & 2 & 4 & $\mathrm{ng}$ & 3 & 2 & $\mathrm{ng}$ & ng & ng \\
\hline$\# 100$ (3) & 2 & 4 & 4 & 2 & 4 & $\mathrm{ng}$ & 3 & 2 & $\mathrm{ng}$ & $\mathrm{ng}$ & ng \\
\hline \#122 (3) & 2 & 4 & 4 & 2 & 4 & ng & 3 & 2 & ng & 4 & 2 \\
\hline \#102 (5) & 2 & 4 & $\mathrm{ng}$ & 2 & 4 & 2 & 3 & 2 & $\mathrm{ng}$ & $\mathrm{ng}$ & ng \\
\hline \#103 (5) & 2 & 4 & ng & 2 & 4 & 2 & 3 & 2 & $\mathrm{ng}$ & $\mathrm{ng}$ & ng \\
\hline$\# 13$ (6) & 2 & 4 & $\mathrm{ng}$ & 2 & $\mathrm{ng}$ & $\mathrm{ng}$ & 3 & 2 & ng & $\mathrm{ng}$ & $>4$ \\
\hline$\# 14$ (6) & 2 & 4 & 4 & 2 & 4 & ng & 3 & 2 & ng & ng & ng \\
\hline$\# 40$ (6) & 2 & 4 & $\mathrm{ng}$ & 2 & 4 & ng & $\mathrm{ng}$ & 2 & ng & $\mathrm{ng}$ & $>4$ \\
\hline$\# 128(6)$ & 2 & 4 & 4 & 2 & 4 & 2 & 3 & 2 & ng & $\mathrm{ng}$ & $\mathrm{ng}$ \\
\hline
\end{tabular}

a 2, growth after 2 days incubation; 3 , growth after 3 days incubation; 4 , growth after 4 days incubation; $>4$, growth after more than 4 days incubation; ng, no growth observed for 14 days.

${ }^{b}$ Same results were obtained for the temperatures 50,55 and $70{ }^{\circ} \mathrm{C}$.

maximal temperature for growth not exceeding $70{ }^{\circ} \mathrm{C}$, variable minimal temperature for growth in the range $30^{\circ} \mathrm{C}-45^{\circ} \mathrm{C}$ and no growth at $5 \% \mathrm{NaCl}$. In these studies, most of the strains can grow between $40^{\circ} \mathrm{C}$ and $60^{\circ} \mathrm{C}$. In our study, growth temperature and $\mathrm{pH}$ range suitable for growth were close for all strains whatever their origin, although some differences could be noted. By contrast, strains of $B$. cereus have distinct growth characteristics depending on their genetic groups (Guinebretiere et al., 2008). It has been shown that $B$. cereus strains phenotypic traits are related according to their toxicity, but not according to their origin (Carlin et al., 2006).

Table 2

Growth of $\mathrm{G}$. stearothermophilus strains incubated at different $\mathrm{NaCl}$ concentrations.

\begin{tabular}{|c|c|c|c|}
\hline \multirow[t]{2}{*}{$\begin{array}{l}\text { Strain number } \\
\text { (M13-group) }\end{array}$} & \multicolumn{3}{|c|}{$\begin{array}{l}\text { Time to growth (days) at } \mathrm{NaCl} \\
\text { concentrations (wt/vol) }\left(a_{w}\right)\end{array}$} \\
\hline & $2 \%(0.973)$ & $3 \%(0.971)$ & $4 \%(0.966)$ \\
\hline$\# 1$ (1) & 2 & 3 & $\mathrm{ng}$ \\
\hline \#46 (1) & 2 & ng & ng \\
\hline \#8 (2) & 2 & ng & $\mathrm{ng}$ \\
\hline \#12 (2) & 2 & ng & ng \\
\hline \#28 (2) & 2 & 2 & ng \\
\hline \#52 (2) & 2 & 2 & $\mathrm{ng}$ \\
\hline \#54 (2) & 2 & 2 & $\mathrm{ng}$ \\
\hline \#119 (2) & 3 & $\mathrm{ng}$ & $\mathrm{ng}$ \\
\hline DSM $22(2)$ & 2 & 2 & ng \\
\hline \#59 (3) & 2 & 3 & ng \\
\hline \#66 (3) & 2 & $\mathrm{ng}$ & $\mathrm{ng}$ \\
\hline \#67 (3) & 2 & 3 & ng \\
\hline$\# 100$ (3) & 2 & 2 & 3 \\
\hline \#122 (3) & 2 & 2 & $\mathrm{ng}$ \\
\hline \#102 (5) & 2 & 3 & 3 \\
\hline \#103 (5) & 2 & $\mathrm{ng}$ & $\mathrm{ng}$ \\
\hline \#13 (6) & 2 & ng & ng \\
\hline \#14 (6) & 2 & 2 & $\mathrm{ng}$ \\
\hline$\# 40$ (6) & 2 & 2 & 3 \\
\hline$\# 128(6)$ & 2 & ng & $\mathrm{ng}$ \\
\hline
\end{tabular}

ng, no growth observed after 14 days.
Table 3

Sporulation of G. stearothermophilus strains from different genotypic groups.

\begin{tabular}{|c|c|c|c|c|c|c|c|}
\hline \multirow[t]{3}{*}{$\begin{array}{l}\text { Strain number } \\
\text { (M13 group) }\end{array}$} & \multicolumn{7}{|c|}{$\begin{array}{l}\% \text { of sporulation after incubation at different } \\
\text { temperature }\left({ }^{\circ} \mathrm{C}\right) \text { and } \mathrm{pH} \text { conditions }{ }^{\mathrm{a}}\end{array}$} \\
\hline & \multicolumn{2}{|l|}{$70^{\circ} \mathrm{C}$} & \multicolumn{3}{|l|}{$55^{\circ} \mathrm{C}$} & \multirow{2}{*}{$\frac{45^{\circ} \mathrm{C}}{\mathrm{pH} 7.0}$} & \multirow{2}{*}{$\frac{40^{\circ} \mathrm{C}}{\mathrm{pH} 7 . \mathrm{C}}$} \\
\hline & pH 7.0 & pH 7.0 & pH 6.0 & pH 5.5 & pH 5.0 & & \\
\hline \#1 (1) & 12 & 100 & 90 & 80 & nt & 7 & 2 \\
\hline$\# 46$ (1) & 5 & 100 & 95 & 95 & nt & 0 & nt \\
\hline \#8 (2) & 0 & 45 & 2 & 30 & nt & 90 & nt \\
\hline$\# 12$ (2) & 0 & 70 & 95 & 10 & nt & 0 & 0 \\
\hline \#28 (2) & 1 & 50 & 20 & 50 & 1 & 95 & 0 \\
\hline \#52 (2) & 80 & 90 & 72 & 15 & nt & 20 & 1 \\
\hline \#54 (2) & 35 & 80 & 10 & 10 & nt & 80 & 0 \\
\hline$\# 119$ (2) & 0 & 80 & 70 & 40 & nt & nt & nt \\
\hline DSM $22(2)$ & 0 & 95 & 60 & nt & 0 & 5 & 0 \\
\hline \#59 (3) & 0 & 70 & 60 & 15 & nt & 0 & nt \\
\hline \#66 (3) & 0 & 95 & 95 & 90 & nt & 95 & 4 \\
\hline \#67 (3) & 1 & 99 & 80 & 10 & nt & 90 & 0 \\
\hline$\# 100$ (3) & 0 & 70 & 60 & 65 & nt & 0 & 0 \\
\hline \#122 (3) & 0 & 75 & 70 & 60 & 60 & 30 & 7 \\
\hline \#102 (5) & 0 & 90 & 80 & 20 & nt & 23 & nt \\
\hline \#103 (5) & 5 & 40 & 10 & 2 & nt & 2 & nt \\
\hline$\# 13$ (6) & 0 & 50 & 45 & 40 & nt & 0 & nt \\
\hline \#14 (6) & 0 & 85 & 15 & 10 & nt & 5 & 7 \\
\hline$\# 40$ (6) & 0 & 90 & 60 & $\mathrm{nt}$ & nt & 85 & nt \\
\hline$\# 128$ (6) & 2 & 60 & 10 & 0 & nt & 90 & 0 \\
\hline
\end{tabular}

nt, not tested.

a The number is the percentage of spores among total cells formed on sporulation medium after 21 days.

The percentage of spores produced as a function of initial $\mathrm{pH}$ and incubation temperature was determined for the same 20 strains (Table 3). The most efficient condition for spore production was $\mathrm{pH} 7.0$ and $55^{\circ} \mathrm{C}$ for all strains except for three isolates (\#8, \#28 and \#128), which formed more spores at $45^{\circ} \mathrm{C}$, and isolate \#12, which formed more spores at $\mathrm{pH}$ 6.0. Only isolate \#52 produced $85 \%$ of spores at $70{ }^{\circ} \mathrm{C}$, whereas all the others produced less than $35 \%$ or none.

\subsection{Heat-resistance of selected G. stearothermophilus strains}

Survival curves were followed on 3.5 to $>6 \log$ reduction. A satisfactory fitting was obtained with at least one of the survival models, as shown by low RSS (Table 4) and by visual examination of graphs (data not shown). The $t_{5 D}$ value (time necessary to inactivate 5-log of population) at $120^{\circ} \mathrm{C}$ was used to compare heat-resistance of spores produced at $\mathrm{pH} 7.0$ and $55^{\circ} \mathrm{C}$ (Table 4). Strains \#28, \#52, \#67 and DSM 22 exhibited a $t_{5 D}$ value above $10 \mathrm{~min}$. The $t_{5 D}$ values were between 6.4 and 8.9 min for seven strains and below $4.9 \mathrm{~min}$ for six strains. The lowest $t_{5 D}$ value, $1.9 \mathrm{~min}$, was obtained for isolate \#119. Lastly, strains \#8, \#14 and \#46 exhibited log-reduction greater than 7.0 in $0.5 \mathrm{~min}$ and $t_{5 D}$ was arbitrarily set at $<0.5 \mathrm{~min}$. The spore wet heat-resistance differed significantly between strains (no overlap in the $95 \%$ confidence intervals of many strains). These data were compared to those recorded in a metaanalysis of $G$. stearothermophilus heat-resistance parameters (Rigaux et al., 2013). At $120^{\circ} \mathrm{C}$ and $\mathrm{pH} 6.5$ to $7.0, D$ values range between $1.3 \mathrm{~min}$ and $16.7 \mathrm{~min}$ with a median at $3.0 \mathrm{~min}$, which gives $t_{5 d}$ between $6.5 \mathrm{~min}$ and $84 \mathrm{~min}$, with a median at 15.0 . The $t_{5 d}$ values reported in this work, although not all based on log-linear reduction, are clearly in the lower range of these previous observations.

Three out of the four most heat-resistant strains ( $t_{5 D}>10 \mathrm{~min}$ ) were able to grow at the lowest temperature $\left(40^{\circ} \mathrm{C}\right)$, at the lowest initial $\mathrm{pH}$ ( $\mathrm{pH} 5.0$ ) or with $3 \% \mathrm{NaCl}$. The fourth strain could grow in the same conditions except at the lowest initial $\mathrm{pH}$. Thus spore heat-resistance was related to the ability to grow under the most 
Table 4

Heat resistance at $120^{\circ} \mathrm{C}$ of G. stearothermophilus spores produced at $55^{\circ} \mathrm{C}$ and $\mathrm{pH}$ 6.5 .

\begin{tabular}{lrlll}
\hline $\begin{array}{l}\text { Strain number } \\
\text { (M13-group) }\end{array}$ & $\begin{array}{c}t_{5 D} \text { value } \\
(\mathrm{min})\end{array}$ & $\begin{array}{l}\text { 95\% confidence } \\
\text { interval }\end{array}$ & RSS $^{\mathrm{a}}$ & log-model $^{\mathrm{b}}$ \\
\hline$\# 1(1)$ & 8.0 & {$[7.7: 8.4]$} & 0.147 & Biphasic \\
$\# 46(1)$ & $<0.5$ & & & \\
$\# 8(2)$ & $<0.5$ & & & \\
$\# 12(2)$ & 6.6 & {$[6.3: 7.0]$} & 0.708 & Weibull \\
$\# 28(2)$ & 11.0 & {$[10.8: 11.3]$} & 0.011 & Biphasic \\
$\# 52(2)$ & 12.1 & {$[11.5: 13.1]$} & 0.197 & Weibull \\
$\# 54(2)$ & 8.1 & {$[7.8: 8.4]$} & 0.079 & Biphasic \\
$\# 119(2)$ & 1.9 & {$[1.8: 2.1]$} & 0.032 & Weibull \\
DSM 22 (2) & 12.4 & {$[11.8: 13.0]$} & 0.234 & Linear \\
$\# 59(3)$ & 3.6 & {$[3.4: 3.9]$} & 1.097 & Linear \\
$\# 66(3)$ & 7.1 & {$[6.7: 7.6]$} & 0.400 & Biphasic \\
$\# 67(3)$ & 10.7 & {$[10.4: 11.0]$} & 0.260 & Weibull \\
$\# 100(3)$ & 2.7 & {$[2.6: 2.9]$} & 0.141 & Linear \\
$\# 122(3)$ & 4.9 & {$[4.8: 5.1]$} & 0.162 & Weibull \\
$\# 102(5)$ & 4.5 & {$[4.3: 4.6]$} & 0.269 & Weibull \\
$\# 103(5)$ & 3.8 & {$[3.7: 3.8]$} & 0.031 & Weibull \\
$\# 13(6)$ & 8.9 & {$[8.3: 9.7]$} & 0.273 & Biphasic \\
$\# 14(6)$ & $<0.5$ & & & \\
$\# 40(6)$ & 6.4 & {$[6.0: 7.0]$} & 0.099 & Weibull \\
$\# 128(6)$ & 6.6 & {$[6.5: 6.7]$} & 0.006 & Biphasic \\
\hline
\end{tabular}

a RSS, Residual Sum of Squares.

b Models: "linear" when log-reduction was linear with time, "Weibull" when a shoulder was observed at the beginning, and "biphasic" when curves displayed a linearity with latency.

extreme temperature and $\mathrm{pH}$ values, although the relationship was not reciprocal. This relationship was also observed among emetic $B$. cereus strains. The highest heat-resistance of spores was combined with a shift of growth limits towards high temperature (Warth, 1978).

\subsection{Relationship between genotypic group and isolate origin or phenotypic diversity}

The possible relationship between genotypic group and strain characteristics or strain origin was investigated by multiple correspondence analyses (MCA) on several sets of G. stearothermophilus isolates tested in this work.

Several data set were analyzed in each of the three MCA performed: (i) variables "food category", "food product", "food company", "area of isolation", "year of isolation" and "genotypic group" applied to 127 strains (Supplementary Table S1), (ii) variables "vegetable production area", "isolation year" and "genetic group" applied to 51 isolates from canned vegetables (Supplementary Table S1), or (iii) variables "minimal pH of growth", “maximal pH of growth", "minimal temperature of growth", "maximal temperature of growth", "maximal sodium chloride concentration of growth" and "genetic group" applied to 20 isolates (Table 1, Table 2). Genetic grouping in each MCA was unrelated to food category or product, year or area of isolation, or food company, or phenotypic features (data not shown).

\subsection{Conclusions}

Regarding the strains tested in our study, the low phenotypic diversity observed may be explained by two hypotheses: either phenotypic diversity is truly weak within the species giving a monomorphic status for G. stearothermophilus, or the poor diversity observed is related to the common features shared by most of the strains, i.e. spoiled canned food after prolonged storage at $55^{\circ} \mathrm{C}$. However the M13-PCR typing should be an efficient tool to trace G. stearothermophilus in food processing plant. From a practical point of view, and although recommendations should be modulated by the possible presence of other spore-forming bacteria with higher temperature tolerance such as Moorella spp. (André et al., 2013), some process and product conditions regarding G. stearothermophilus as a spoilage hazard in the storage of hightemperature canned food can be proposed. For instance, as G. stearothermophilus can grow and sporulate at temperatures between $40{ }^{\circ} \mathrm{C}$ and $70^{\circ} \mathrm{C}$, processing line temperatures should be maintained above $70{ }^{\circ} \mathrm{C}$. Similarly, salt addition below $3 \%$ does not exhibit a significant effect, while $\mathrm{pH}$ decrease to 5.0 considerably hinders the growth of most strains. Although an increase in salt concentration cannot be used for organoleptic and nutritional reasons, a decrease in food $\mathrm{pH}$ could be investigated, and should result in a lower frequency of long-term canned food spoilage caused by G. stearothermophilus. Lastly, heat-treatment process settings could be re-assessed in the light of a 20 -fold range of variability for $t_{5 D}$ value at $120^{\circ} \mathrm{C}$. Strains \#28, \#52 and DSM 22 were the most tolerant regarding growth conditions, and exhibited high heat resistance at $120^{\circ} \mathrm{C}$ : they can be proposed as test strains in canned food processing design.

\section{Acknowledgments}

This work forms part of author Loïc Durand's PhD thesis. He received a grant from the Association Nationale de la Recherche et de la Technologie, Paris, France. The research work was supported by France AgriMer and by the Conseil Regional Provence-Alpes-Côte d'Azur (DIVERSITHER project). This research work is also a contribution to the activities of the Unite Mixte Technologique Qualiveg. Thanks are due to Dr Olivier Couvert (LUBEM, QUIMPER, France) for treatment of heat resistance data.

\section{Appendix A. Supplementary data}

Supplementary data related to this article can be found at http:// dx.doi.org/10.1016/j.fm.2014.01.015.

\section{References}

Adiguzel, A., Ozkan, H., Baris, O., Inan, K., Gulluce, M., Sahin, F., 2009. Identification and characterization of thermophilic bacteria isolated from hot springs in Turkey, J. Microbiol, Methods 79 (3), 321-328.

André, S., Zuber, F., Remize, F., 2013. Thermophilic spore-forming bacteria isolated from spoiled canned food and their heat resistance. Results of a French ten-year survey. Int. J. Food Microbiol. 165 (2), 134-143. http://dx.doi.org/10.1016/j. ijfoodmicro.2013.04.019.

Ashton, D., Bernard, D., 1992. Thermophilic anaerobic sporeformers. In: Vanderzantz, C., Splittstoesser, D.F. (Eds.), Compendium of Methods for the Microbiological Examination of Foods, third ed. American Public Health Association, Washington, D.C., pp. 309-316.

Carlin, F., Fricker, M., Pielaat, A., Heisterkamp, S., Shaheen, R., Salkinoja Salonen, M., 2006. Emetic toxin-producing strains of Bacillus cereus show distinct characteristics within the Bacillus cereus group. Int. J. Food Microbiol. 109 (1-2), 132138. http://dx.doi.org/10.1016/j.ijfoodmicro.2006.01.022.

Cheng, L., Mu, W., Jiang, B., 2009. Thermostable L-arabinose isomerase from Bacillus stearothermophilus IAM 11001 for D-tagatose production: gene cloning, purification and characterisation. J. Sci. Food Agric. 90 (8), 1327-1333. http:// dx.doi.org/10.1002/jsfa.3938.

Coorevits, A., Dinsdale, A.E., Halket, G., Lebbe, L., De Vos, P., Van Landschoot, A., 2012. Taxonomic revision of the genus Geobacillus: emendation of Geobacillus, G. stearothermophilus, G. jurassicus, G. toebii, G. thermodenitrificans and G. thermoglucosidans (nom. corrig., formerly 'thermoglucosidasius'); transfer of Bacillus thermantarcticus to the genus as G. thermantarcticus comb. nov.; proposal of Caldibacillus debilis gen. nov., comb. nov.; transfer of G. tepidamans to Anoxybacillus as A. tepidamans comb. nov.; and proposal of Anoxybacillus caldiproteolyticus sp. nov. Int. J. Syst. Evol. Microbiol. 62 (Pt 7), 1470-1485. http:// dx.doi.org/10.1099/ijs.0.030346-0.

Couvert, O., Gaillard, S., Savy, N., Mafart, P., Leguerinel, I., 2005. Survival curves of heated bacterial spores: effect of environmental factors on Weibull parameters. Int. J. Food Microbiol. 101 (1), 73-81. http://dx.doi.org/10.1016/j.ijfoodmicro. 2004.10.048.

Dinsdale, A.E., Halket, G., Coorevits, A., Van Landschoot, A., Busse, H.-J., De Vos, P., 2011. Emended descriptions of Geobacillus thermoleovorans and Geobacillus 
thermocatenulatus. Int. J. Syst. Evol. Microbiol. 61 (8), 1802-1810. http:// dx.doi.org/10.1099/ijs,0.025445-0.

Donk, P.J., 1920. A highly resistant thermophilic organism. J. Bacteriol. 5 (4), 373374.

Gibson, T., Gordon, R.E., 1974. The genus Bacillus. In: Buchanan, R., Gibbons, N. (Eds.), Bergey's Manual of Determinative Bacteriology, eighth ed. Williams and Wilkins, Baltimore, pp. 529-550.

Gilson, E., Clement, J.M., Brutlag, D., Hofnung, M., 1984. A family of dispersed repetitive extragenic palindromic DNA sequences in E. coli. EMBO J. 3 (6), 14171421.

Gordon, R.E., Smith, N.R., 1949. Aerobic sporeforming bacteria capable of growth at high temperatures. J. Bacteriol. 58 (3), 327-341.

Goujon, M., McWilliam, H., Li, W., Valentin, F., Squizzato, S., Paem, J., 2010. A new bioinformatics analysis tools framework at EMBL-EBI. Nucleic Acids Res. 38 (Suppl. 2), W695-W699. http://dx.doi.org/10.1093/nar/gkq313.

Guinebretiere, M., Berge, O., Normand, P., Morris, C., Carlin, F., Nguyen-The, C., 2001. Identification of bacteria in pasteurized zucchini purées stored at different temperatures and comparison with those found in other pasteurized vegetable purées. Appl. Environ. Microbiol. 67 (10), 4520-4530. http://dx.doi.org/10.1128/ aem.67.10.4520-4530.2001.

Guinebretiere, M., Nguyen-The, C., 2003. Sources of Bacillus cereus contamination in a pasteurized zucchini puree processing line, differentiated by two PCR-based methods. FEMS Microbiol. Ecol. 43 (2), 207-215. http://dx.doi.org/10.1111/ j.1574-6941.2003.tb01060.x.

Guinebretiere, M., Thompson, F.L., Sorokin, A., Normand, P., Dawyndt, P., Ehling-Schulz, M., 2008. Ecological diversification in the Bacillus cereus group. Environ. Microbiol. 10 (4), 851-865. http://dx.doi.org/10.1111/j.14622920.2007.01495.x.

Guizelini, B., Vandenberghe, L.S., Sella, S.R., Soccol, C., 2012. Study of the influence of sporulation conditions on heat resistance of Geobacillus stearothermophilus used in the development of biological indicators for steam sterilization. Arch. Microbiol. 194 (12), 991-999. http://dx.doi.org/10.1007/s00203-012-0832-z.

Henderson, I., Duggleby, C.J., Turnbull, P.C.B., 1994. Differentiation of Bacillus anthracis from other Bacillus cereus group bacteria with the PCR. Int. J. Syst. Bacteriol. 44 (1), 99-105. http://dx.doi.org/10.1099/00207713-44-1-99.

Hulton, C.S.J., Higgins, C.F., Sharp, P.M., 1991. ERIC sequences: a novel family of repetitive elements in the genomes of Escherichia coli, Salmonella typhimurium and other enterobacteria. Mol. Microbiol. 5 (4), 825-834. http://dx.doi.org/ 10.1111/j.1365-2958.1991.tb00755.x.

Kalogridou-Vassiliadou, D., 1992. Biochemical activities of Bacillus species isolated from flat sour evaporated milk. J. dairy Sci. 75 (10), 2681-2686.

Koeuth, T., Versalovic, J., Lupski, J.R., 1995. Differential subsequence conservation of interspersed repetitive Streptococcus pneumoniae BOX elements in diverse bacteria. Genome Res. 5 (4), 408-418. http://dx.doi.org/10.1101/gr.5.4.408.

Kuisiené, N., Raugalas, J., Čitavičius, D., 2008. Comparative sequence analysis of 16S23S rRNA internal transcribed spacers of the genus Geobacillus. Biologija 54 (1), 1-6. http://dx.doi.org/10.2478/v10054-008-0001-0.

Lupski, J.R., Weinstock, G.M., 1992. Short, interspersed repetitive DNA sequences in prokaryotic genomes. J. Bacteriol. 174 (14), 4525-4529.

Meintanis, C., Chalkou, K.I., Kormas, K.A., Lymperopoulou, D.S., Katsifas, E.A., Hatzinikolaou, D.G., 2008. Application of $r p o B$ sequence similarity analysis, REP-PCR and BOX-PCR for the differentiation of species within the genus Geobacillus. Lett. Appl. Microbiol. 46 (3), 395-401. http://dx.doi.org/10.1111/ j.1472-765X.2008.02328.x.

Nazina, T.N., Tourova, T.P., Poltaraus, A.B., Novikova, E.V., Grigoryan, A.A., Ivanova, A.E., 2001. Taxonomic study of aerobic thermophilic bacilli: descriptions of Geobacillus subterraneus gen. nov., sp. nov. and Geobacillus uzenensis sp. nov. from petroleum reservoirs and transfer of Bacillus stearothermophilus, Bacillus thermocatenulatus, Bacillus thermoleovorans, Bacillus kaustophilus, Bacillus thermodenitrificans to Geobacillus as the new combinations G. stearothermophilus, G. thermocatenulatus, G. thermoleovorans, G. kaustophilus, G. thermoglucosidasius and G. thermodenitrificans. Int. J. Syst. Evol. Microbiol. 51 (2), 433-446. http://dx.doi.org/10.1099/00207713-51-2-433.
Postollec, F., Mathot, A.-G., Bernard, M., Divanac'h, M.-L., Pavan, S., Sohier, D. 1, 2012. Tracking spore-forming bacteria in food: from natural biodiversity to selection by processes. Int. J. Food Microbiol. 158 (1), 1-8. http://dx.doi.org/10.1016/j. ijfoodmicro.2012.03.004.

Prevost, S., Andre, S., Remize, F., 2010. PCR detection of thermophilic spore-forming bacteria involved in canned food spoilage. Curr. Microbiol. 61 (6), 525-533. http://dx.doi.org/10.1007/s00284-010-9648-8.

Rigaux, C., Denis, J.-B., Albert, I., Carlin, F., 2013. A meta-analysis accounting for sources of variability to estimate heat resistance reference parameters of bacteria using hierarchical Bayesian modeling: estimation of $D$ at $121.1^{\circ} \mathrm{C}$ and $\mathrm{pH} 7$, $z_{T}$ and $z_{p H}$ of Geobacillus stearothermophilus. Int. J. Food Microbiol. 161 (2), 112120. http://dx.doi.org/10.1016/j.ijfoodmicro.2012.12.001.

Rivero, C.W., De Benedetti, E.C., Sambeth, J.E., Lozano, M.E., Trelles, J.A., 2012 Biosynthesis of anti-HCV compounds using thermophilic microorganisms. Bioorg. Med. Chem. Lett. 22 (19), 6059-6062. http://dx.doi.org/10.1016/j.bmcl. 2012.08.045.

Ronimus, R.S., Parker, L.E., Turner, N., Poudel, S., Rückert, A., Morgan, H.W., 2003. A RAPD-based comparison of thermophilic bacilli from milk powders. Int. J. Food Microbiol. 85 (1â€"2), 45-61. http://dx.doi.org/10.1016/S0168-1605(02)00480-4.

Rückert, A., Ronimus, R.S., Morgan, H.W. 2004. A RAPD-based survey of thermophilic bacilli in milk powders from different countries. Int. J. Food Microbiol. 96 (3), 263-272. http://dx.doi.org/10.1016/j.ijfoodmicro.2004.03.020.

Seale, R.B., Dhakal, R., Chauhan, K., Craven, H.M., Deeth, H.C., Pillidge, C.J., 2012. Genotyping of present-day and historical geobacillus species isolates from milk powders by high-resolution melt analysis of multiple variable-number tandemrepeat loci. Appl. Environ. Microbiol. 78 (19), 7090-7097. http://dx.doi.org/ 10.1128/aem.01817-12.

Sevenier, V., Delannoy, S., André, S., Fach, P., Remize, F., 2012. Prevalence of Clostridium botulinum and thermophilic heat-resistant spores in raw carrots and green beans used in French canning industry. Int. J. Food Microbiol. 155 (3), 263-268. http://dx.doi.org/10.1016/j.ijfoodmicro.2012.02.009.

Sievers, F., Wilm, A., Dineen, D., Gibson, T.J., Karplus, K., Li, W., 2011. Fast, scalable generation of high-quality protein multiple sequence alignments using Clustal Omega. Mol. Syst. Biol. 7.

Smith, N.R., Gordon, R.E., 1957. Bacillus. In: Breed, R., Murray, E., Smith, N.R. (Eds.), Bergey's Manual of Determinative Bacteriology, seventh ed. Balliere, Tindall, Fox, London, pp, 613-634.

Stern, M.J., Ames, G.F.-L, Smith, N.H., Clare Robinson, E., Higgins, C.F., 1984. Repetitive extragenic palindromic sequences: a major component of the bacterial genome. Cell 37 (3), 1015-1026.

Versalovic, J., Schneider, M., de Bruijn, F.J., Lupski, J.R., 1994. Genomic fingerprinting of bacteria using repetitive sequence-based polymerase chain reaction. Methods Mol. Cell. Biol. 5, 25-40.

Warth, A.D., 1978. Relationship between the heat resistance of spores and the optimum and maximum growth temperatures of Bacillus species. J. Bacteriol. 134 (3), 699-705.

Weng, F.Y., Chiou, C.S., Lin, P.H.P., Yang, S.S., 2009. Application of recA and rpoB sequence analysis on phylogeny and molecular identification of Geobacillus species. J. Appl. Microbiol. 107 (2), 452-464. http://dx.doi.org/10.1111/j.13652672,2009.04235.x.

White, D., Sharp, R.J., Priest, F.G., 1993. A polyphasic taxonomic study of thermophilic bacilli from a wide geographical area. Antonie Van Leeuwenhoek Int. J Gen. Mol. Microbiol. 64 (3-4), 357-386.

Xu, D., Côté, J.-C., 2003. Phylogenetic relationships between Bacillus species and related genera inferred from comparison of 3' end 16S rDNA and 5' end 16S-23S ITS nucleotide sequences. Int. J. Syst. Evol. Microbiol. 53 (3), 695-704. http:// dx.doi.org/10.1099/ijs.0.02346-0.

Zeigler, D.R., 2003. Gene sequences useful for predicting relatedness of whole genomes in bacteria. Int. J. Syst. Evol. Microbiol. 53 (6), 1893-1900. http:// dx.doi.org/10.1099/ijs.0.02713-0.

Zeigler, D.R., 2005. Application of a recN sequence similarity analysis to the identification of species within the bacterial genus Geobacillus. Int. J. Syst. Evol. Microbiol. 55 (3), 1171-1179. http://dx.doi.org/10.1099/ijs.0.63452-0. 